\title{
The Journey of Mapping the Entire Destination Lifecycle
}

\author{
Tomy Andrianto1, Ahmad Hudaiby Galih Kusumah² \\ Department of Business Administration, Politeknik Negeri Bandung, Bandung, Indonesia ${ }^{1}$ \\ Jl. Gegerkalong Hilir, Ciwaruga, Bandung, Jawa Barat, Indonesia \\ Email: tomyandrianto@polban.ac.id
}

Master of Tourism Program, Universitas Pendidikan Indonesia, Bandung, Indonesia ${ }^{2}$

Jl. Dr. Setiabudi No.229, Isola, Kec. Sukasari, Kota Bandung, Jawa Barat 40154

Email: galih@upi.edu

\begin{abstract}
The two destination life cycle models proposed by Plog (1974) and Butler (1980) have been recognizing by most of the tourism destination scholars. Questions tend to arise on the possible use of these models to map the entire destination life cycle from the beginning. Therefore, this study aims to discuss the possibility of entire lifespan of tourism destination by using the destination life cycle models from Plog and Butler. This research analyses the strengths and weaknesses of the models revealed from existing studies using critical inputs of the tourism industry. The main difference between the famous models, i.e. Butler and Plog lies in the authors' background and the approach of the different themes. Complexity factors such as multi-market, time boundaries, political agenda, market evolution/ access, mode of transportation, and technological innovation, makes it impossible to map the entire destination life cycle confidently. The ability to innovate reduces the relevancy of life cycle models. Therefore, the DMO needs to deal with the changes associated with increasing the destination's values to avoid stagnation or decline in stages.
\end{abstract}

Keywords: destination life cycle model; destination lifespan; life cycle stages; complexity factors; Butler and Plog.

\section{A. INTRODUCTION}

The destination life cycle models were initially developed in the 1970s. Plog (1974) proposed a model based on the psychographic position of the destination while the Tourism area cycle of evolution was established by Butler (1980). They received great attention from scholars during the discourse of the subject (McKercher, 2018). Plog's model was commended for "its elegant simplicity" (Litvin, 2006), while Butler's model was acknowledged for "its ability to function as a cross-sectional analytical tool ...." (McKercher, 2005). However, both have weaknesses that have been widely discussed.

These two models can map a single destination product (McKercher, 2005; Prideaux, 2000), at certain periods or stages (McKercher 2018; Prideaux, 2000) and tend to ignore both distance decay as well as the concept of cultural distance (McKercher, 2005b). However, it is difficult to use the models to explain the life cycle of tourism destination. This led to the emergence of the research question on the possibility of the existing models to describe the destination life cycle in its entirety from the initial sequence to the end. This is in addition to considering all the amalgam of products and critical inputs in the development of a particular destination.

This study discusses the possibility of the life cycle models to convincingly delineate the entire tourism destination lifespan from the beginning to the end. This research compares the strengths and weaknesses of current destination life cycle models reported in various articles as well as their importance in recent tourism industrial trends. Plog and Butler assumed that their model is useful 
in mapping the entire destination life cycle, although from a different perspective (McKercher, 2005 , 2018). However, there is a tendency to posits that it tends to get complicated when used to delineate the destination life cycle as a whole and currently considered unimportant for business purposes.

\section{B. LIFE CYCLE MODEL}

\section{Plog's Pscyhograpic positions of destinations (PPD)}

Plog's model was initially stated in the 1972 Travel and Tourism Research Conference (TTRA). However, in 1974 it was published in Cornel Quarterly entitled "The Reason Destination Areas Rise and Fall in Popularity." In 2001 Plog revised its title to "dependent psychocentric," "midcentric," "allocentric," as well as "centric dependable and venture" (Goeldner, 2016). Plog's model is claimed to be one of the most discussed destination life cycle models in tourism. The revised model is shown in figure 1.

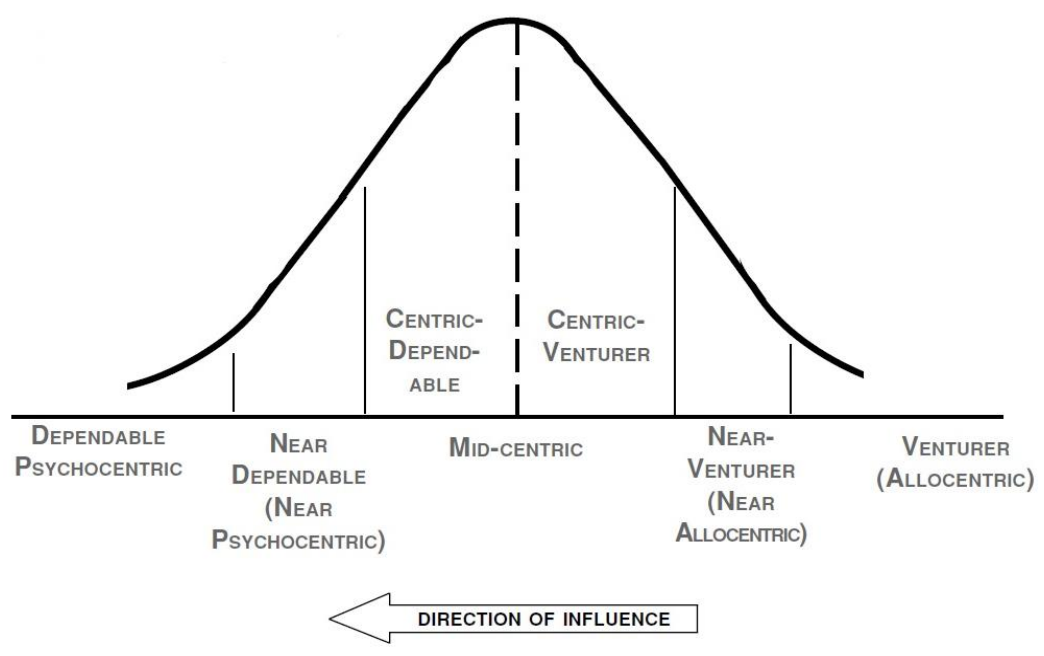

Figure 1. Psychographic personality types (Plog, 2001, p. 16)

The essence of the Plog's model is to determine the continual success or failure of destinations at each phase due to the diverse psychographic personalities of the visitors as well as market demand (Plog, 1974, 2001). Plog's (2001) reported that there is a possibility of mapping the entire destination life cycle from the beginning, monitoring its growth, maturity and eventual decline based on personality types, merely referred to as PPD (Psychographic positions of destination). It is believed that Plog's life cycle model illustrates the popularity based on the various views of the tourists, such as interests and those that eventually got bored and decided not to return at the end.

According to Plog (2001), individuals in the "Midcentrics" category are described as the regularly visiting tourist types compared to the dependable psychocentrics and venturers, which were discovered to be normally distributed (Plog, 2001). Plog stated that a destination is initially visited by the "venturers," followed by the "midcentrics" and finally the "dependable psychocentrics." It was further stated that the model was able to describe the entire destination life cycle from the beginning to the end. However, the question is to ascertain the possibility of applying the PPD as well as considering the distance decay and cultural distance concept (McKercher, 2018), which is concisely reported in the contrast and discussion section. 


\section{Butler's Tourism area life cycle (TALC)}

McKercher (2005) stated that Butler's model was initially published as a proceeding in the special edition of Canadian geography. In addition, the material which had been developed since 1972, was previously reported at the Canadian Geographers Association meeting held the same year. This model has been severally revised and is alleged to be a commonly discussed theory in tourism (McKercher, 2005a).

The Butler's model established in 1980 was titled "Tourism Area Cycle of Evolution" before it was renamed Tourism Area Life Cycle (TALC). It was initially adopted from the concept of a product's life cycle (Butler, 1980). A detailed description of the original model is shown in figure 2,

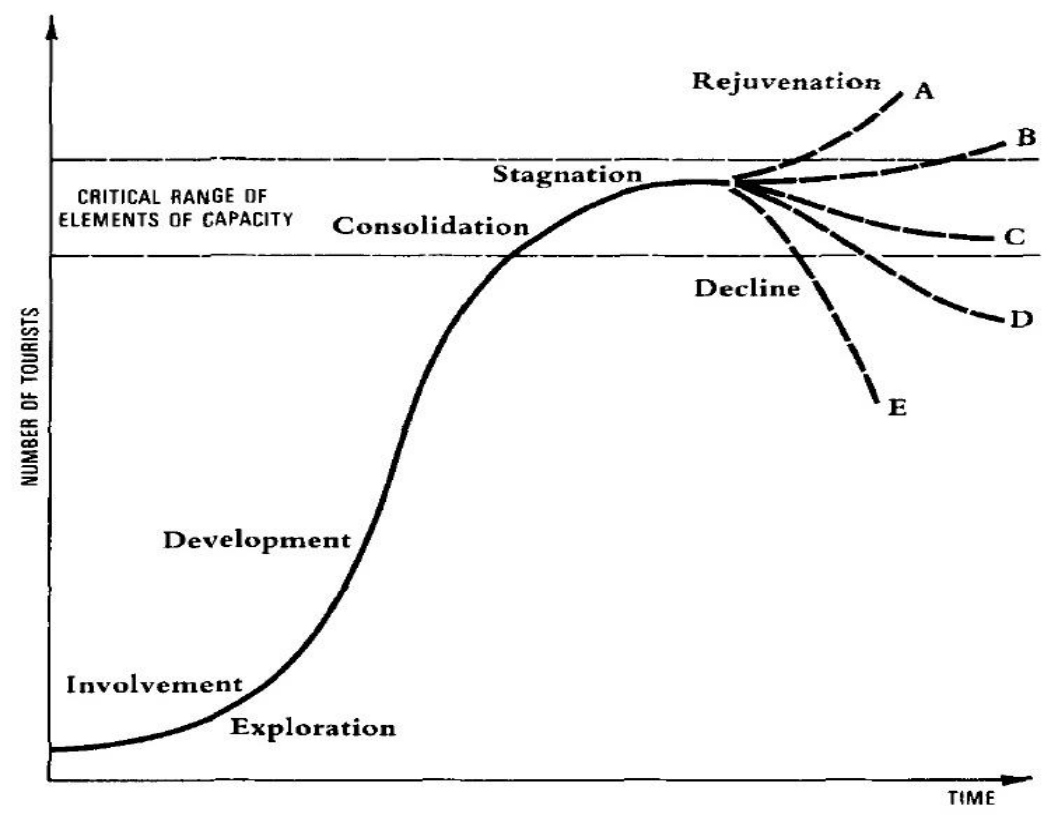

Figure 2. Tourism Area Cycle of Evolution (Butler, 1980, p. 7)

In conclusion, Butler (1980) stated that the growth of tourist areas depends on the carrying capacity, and it can eventually complete the entire life cycle stages.

An area that lacks access, facilities, and local knowledge tend to attract few visitors. However, the provision of improved facilities, marketing and awareness or information dissemination, leds to an increase in their numberas well as the rapid popularity of the area. Eventually, there is a decline in the rate of increase as the carrying capacities are reached.

According to Butler (1980), at the initial stage, destination products attracted only a few tourists. Furthermore, an increase in carrying capacity causes an increase in tourist visits, as well as the need to undergo various other steps. It eventually migrates into a period of stagnation; however, when its function starts to deteriorate, the destination encounters five choices from a gradual increase to stability and then a decline (Butler, 1980). The carrying capacity implicitly stated by Butler is one of the most significant discoveries in the tourism world (McKercher, 2005).

It simply means that this model is considered capable of measuring destination product over a certain period within their capacity. Subsequently, this led to the emergence of a series of questions such as the possibility that destination consists of a single product in a finite capacity and the duration of each stage. The explanations are stated in the contrast and discussion section. 


\section{METHOD}

To understand the mapping of destination lifecycles, articles from Plog (1974) and Butler (1980) selected as the main references. These two classic tourism articles were chosen because they were the most used references by scholars when conducting studies on the destination lifecycle. To review these two articles, a review of the related literatures was also carried out. These related articles are obtained by searching through article databases, namely google scholar, science direct, and EBSCOhost. By searching for the keywords 'Plog', 'Butler,' and 'destination lifecycle', we found 132 articles discussing the destination lifecycle of Plog and Butler. After screening the literature based on the topic and aim in the abstract, 21 articles were selected which were deemed suitable for the purpose of this study. An in-depth study was then carried out on the entire article to understand the mapping of the destination lifecycle. The content analysis approach is carried out to determine the dominant themes, cycle phases, and elements that affect the destination lifecycle.

\section{CONTRAST AND DISCUSSION}

Comparing and discussing the two, the models tend to be lengthy and broad because Butler and Plog had different scientific backgrounds, namely geography and psychology, respectively. The two models also have entirely different theme approaches, irrespective of the fact that they are interrelated. Therefore this section focuses on whether the two models are able to delineate the entire life cycle based on the distinction and criticisms.

\section{Dominant theme and product}

The dominant themes in both Plog's and Butler's models are psychographic personality position and carrying capacity, respectively. As stated earlier, the Plog's Model examines the destination life cycle of a visitor's personality, which was reported to be either "venturer or allocentric," "dependable psychocentrics" (Plog, 2001). Meanwhile, Butler stated the limitations of carrying capacity possessed by the destination as well as its development (Butler, 1980). Irrespective of their different factors, they are interconnected.

A certain critic relating to PPD was stated by Litvin (2006) and Litvin and Smith (2016). They reported that psychocentric and allocentric theories are widely taught in tourism, despite the fact that an insignificant relationship exists between personality and choice of destination (Smith, 2006). It is evident that adventurous people regularly visit tourist sites compared to psychographics, mid-centric, and vice versa. According to Litvin (2006), it is an undeniable fact that distance, time, money, and motivation also plays a crucial role (Litvin, 2006). McKercher (2005) reported that people have different perceptions of allocentric or psychocentric destination. For example, Plog, an American citizen, needs to consider destinations in Asia, while Asians tend to prefer America or Europe (McKercher, 2005).

Conversely, the theme of Butler's model is simple and straightforward. The model that adopts a product life cycle is easier to understand. Nevertheless, tourism destinations are not developed by single products, rather it is affected by various factors that support the carrying capacity (McKercher, 2005). In order to support this hypothesis, Weaver (2000) stated that the carrying capacity is complex, and needs to be reviewed from a social rather than an ecological point of view. This, therefore, implies that it is unlimited and is alterable depending on the treatment. For example, innovation and technologies tend to improve the carrying capacity at all stages.

In addition, carrying capacity has diverse interpretations, as well as several ways of modifying its limits (Getz, 1992). This means that managers need to possess the ability to improve destinations in order to sustain the developmental stage, thereby avoid migrating into the stagnation or decline stage. Conversely, Singh (2011) stated that energy depreciates when it is overused, and this limits the carrying capacity as well as the number or the quality of visits. Singh further stated that various rules are conducted to reduce the number of visitors, thereby emphasizing that the carrying capacity is finite. 
However, the discussions show that the dominant themes in both models, particularly Plogs, is unable to analyze the entire destination life cycle. This was because they illustrated tourists as a market rather than focusing on destination development sequences (McKercher, 2005). It was further reported that it continuously served multiple purposes in accordance with the destinationmarket matrix. The author acknowledged the possibility of a flexible Tourist market as well as modified carrying capacity, depending on the treatment. For example, a famous iconic destination has better access to the market than other places.

\section{Lifecycle stages}

Plog and Butler both divided the lifecycle into six phases, as well as their respective differences according to the dominant factors. They assumed that from the beginning and endpoint of each stage is undoubtedly traversed. However, Kusumah and Nurazizah (2016) stated that it is not compulsory to develop every step on a destination or product life cycle model. This means that it is not necessary to indulge in the entire process.

Furthermore, stages rely on changes in the fundamental economic law, such as supply and demands, which continuously proceeds to respond (Tooman, 1997). In other words, changes in each stage imply the number of requests or a lack of supply and demand (or vice versa). There is no need always to monitor the phases. It either returns to the previous level or immediately rises, assuming there are a low supply and high demand. The statement theory from Plog's model stated that all destinations need to experience a decline eventually was doubted by McKercher (2005).

Moreover, according to the Resort destination spectrum (RDS) developed by Prideaux (2000), destinations undergo similar evolutionary stages severally, irrespective of the fact that they do not eventually complete each phase. It simply means that not all destinations migrate to the next step, as some are either jumped or even declined. Therefore, some remain in the same phase, while others need a short period, and some have not even undergone the initial stages. The RDS of Prideaux (2000) is shown as follows,

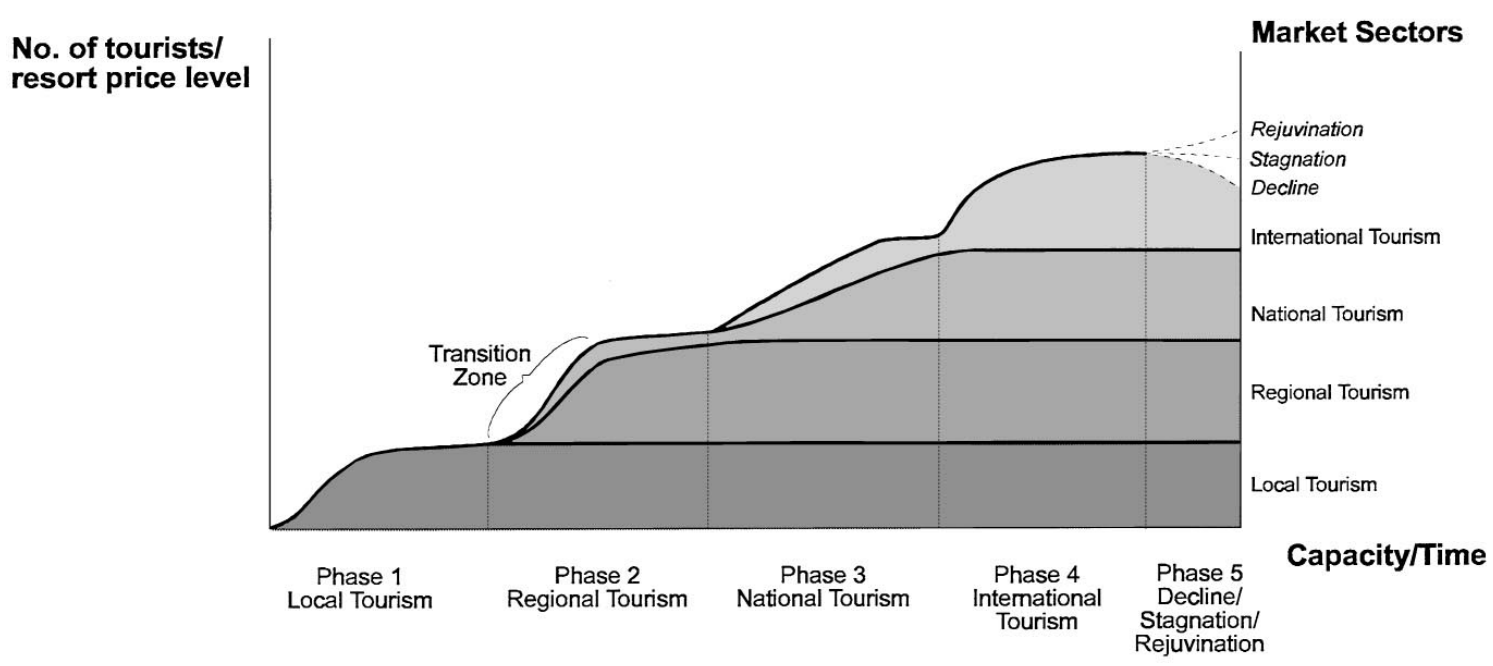

Figure 3. Prideaux's Research Development Spectrum (2000, p. 233)

Prideaux (2000) combined the essential themes in both Plog's and Butler' model with their complexities in the tourism industries. For example, the changes in market trends affect the evolution of destination (McKercher 2018). Prideaux's model is more complex because it utilized both capacity and market in various phases, and it is also different from Plogs' that focussed on the market while Butler on product. However, the author reported Prideaux's model is focussed on resort development phases rather than convincingly illustrating the life cycle as a whole.

14 Jurnal Kepariwisataan: Destinasi, Hospitalitas dan Perjalanan, Volume 5 Nomor 1, 2021: 10-19 
Conversely, the existing models were unable to delineate the entire stages of the destination life cycle, while Prideaux is focused on resort development. The author stated that the models were only able to identify and understand the various stages; however, they were unable to predict the future. Subsequently, any user that applies any of the models in the future needs to adjust to its critical elements to attain its primary purpose (Prideaux, 2000).

\section{Time Frame}

It is necessary to understand either models' time frame to examine the duration of each or the entire life cycle stages. Plog's (1974) model is time-limited or closed-ended and- gradually migrates into unavoidable phases. The duration is not stated because the process is affected by tourist personality. However, based on previous discussions, McKercher (2005) doubted the association of the model to the various perceptions of the market concerning a particular destinations. This means that it does not guarantee the time frame required to identify the sequences. For example, the different impressions of the diverse market are crucial in determining each stage's duration.

Meanwhile, one of the advantages of Butler's model (1980) is that the X and Y axes are open-ended (McKercher, 2005), therefore it is not time-bound and unable to develop continuously. The horizontal line showing the time and numbers of tourists is infinite and tends to grow continuously. McKercher (2005) stated that "Evolution is defined as a continuous change from simple to complex form," while the life cycle is "a series of stages that characterizes the life of an individual or entity." Singh (2011) supported the hypothesis by reporting that both lack specific time limitation, however when the need arises to compare them, the life cycle is relatively shorter and starts from the beginning to the end of the period, while evolution is continuous. Nevertheless, Butler renamed the model life cycle over the years (McKercher, 2005), despite remaining open-ended.

In accordance with the model, the destination continues to evolve from time to time without boundaries; its duration varies in the different stages. The research conducted by Choy (1992) reported that a similar life cycle pattern was exhibited by five top destinations on the South Pacific Island from 1946 - 1988. During that time, Hawaii never migrated into the decline stage, while other destinations had at least once; however, they continued to grow (Choy, 1992). It also means that Butler's model was unable to precisely determine the time frame required for the entire destination life cycle.

However, it was difficult to state the exact time needed to complete each stage as well as migrates to the next step in both models. According to the research conducted on the Niagara Falls, Getz (1992) stated that it was challenging to apply the Butler's model at a later stage after the stagnant or declined visitors was discovered. It was further reported that political agendas play an essential role in the development of destinations because they invest in hotels, thereby increasing the number of tourists (Getz, 1992). The author stated that in the contest of the life cycle, the time frame needs to be set based on specific situations or conditions. Otherwise, it tends to last for a long period without even migrating to the next stage, and this makes it impossible to map the entire life cycle in a lifetime. Although, this is possible assuming the research was conducted from time to time till the end of the destination cycle.

\section{Tourist and local response}

This section addresses the relationship between tourists and local responses, namely local government, tourism industries, and the residents. The existing model is debatable and delineates the entire destination life cycle based on the market or local people. According to Singh (2011), the relationship between personality, tourists' perception of carrying capacity, and community behaviour are vital for the development of destinations at various stages of Butler's model. It ensures the current position of the life cycle stages and ensures that the tourists and locals have similar perceptions and understanding of a particular destination.

Conversely, Plog's model attempt to understand the destination life cycle in accordance with the tourists' personality. In reality, tourists visit destinations that do not complement their characters 
(Litvin, 2006). According to a research conducted on 290 University students in Singapore, it was discovered that most of the respondents visited psychocentrics and near psychocentrics destinations (74\%), followed by midcentrics (23\%) and near-allocentrics (3\%). This is different from Plog $(1974,2001)$, which reported that midcentric destination was frequently visited than psychocentrics or allocentrics. However, the result from Litvin's research is also supported by the theory of distance decay, which states that distance and time positively affect the visitor's demand (McKercher, 2018). The closest destinations are likely to be frequently visited than farther distances, requiring more extended time, which causes a decrease in demand (McKercher et al., 2008).

One of the strengths of Plog's model is in terms of studying the different types of visitors' personalities, including the preferences to select a suitable destination. Pearce (1988) also reported that no matter the travel routines, individuals choose a more adventurous trip that complements their original personality. Finally, it is reinforced by Goeldner (2016), which stated that the core of Plog's model discloses that consumer behaviour changes over time. This simply means that different personalities visit a particular destination.

The existing models were not able to adequately describe the destination life cycle from the tourists' perspective and the functions of local parties at each stage or time. Tourist's personality type and perception of the locals concerning the carrying capacity changes during the process. In conclusion, it is essential to synchronize the impression of the diverse markets in developing destination carrying capacity to map the entire life cycle convincingly.

\section{Business Purpose}

Existing destination life cycle models do not explicitly address its importance in the context of business purpose. Several scholars tested Butler's model, which showed that it is capable of realizing a destination's business position at a particular time. It was supported by Getz (1992), which stated that the model was able to detect the existence of destinations in certain positions, using the Isle of Man as a case study. Furthermore, it is not a strategy; rather, it is an analytical-tool utilized in the development of tourist destinations (Getz, 1992). This was also supported by Opperman (1998), which reported that the model does not explicitly state the reason behind the destination shift.

Several scholars doubted the use of the Plog model to illustrate the stages of the destination life cycle from the visitor's perspective, not to mention the entire process. McKercher (2005) initially questioned the model's inability to understand the destination's positions from visitor's perspectives and the evolution of the market. In addition, Litvin (2016) also reported three weaknesses of the model. First, it does not pay attention to those factors that drive tourists, the kind of activities carried out, and types of transportation used. As an example, Litvin (2016) stated that these three weaknesses were also detected during tourists visiting Alaska as backpackers or using cruise ships package. Therefore, Plog's model only understands the development of destinations from the tourists' perspective.

It is evident that practitioners, such as DMO, utilize the destination life cycle to understand the current position of the destination and strengthen it by conducting necessary activities. In accordance with enhancing the position, Haywood (1986) stated seven underlying forces that affect destination, namely rivalry and development of new tourist areas, substitutes for tourism experience, environmentalist and public personnel, travel industries and intermediaries, tourists, and governmental policies. For example, the evolution of destination needs to create diverse experiences (McKercher, 2005). Cooper and Jackson (1989) reported that Butler's TALC model serves as an analytical tool used to understand the development of destinations; however, it has limitations to offer direct guidance.

At the end of this section, the author concluded that investigating the entire destination life cycle is not as necessary as understanding the current position to survive or win the competition among 
rivalries. Subsequently, industries only need to identify their destination product in the market. Ultimately, a summary of the hypothesis based on contrast and discussion is shown in Table 1,

Table 1. Summary of Argument

\begin{tabular}{|c|c|c|c|}
\hline Key Point & Plog & Butler & Argument \\
\hline $\begin{array}{l}\text { Dominant } \\
\text { theme and } \\
\text { product }\end{array}$ & $\begin{array}{l}\text { No correlation between } \\
\text { personality and } \\
\text { destination selection } \\
\text { (Litvin, 2006), an } \\
\text { individual's perception is } \\
\text { different (McKercher, } \\
2005 \text { ) }\end{array}$ & $\begin{array}{l}\text { No single product, Carrying } \\
\text { capacity is complex, multi- } \\
\text { interpretation, and needs to } \\
\text { be modified. (McKercher, } \\
\text { 2005; Getz, 1992) }\end{array}$ & $\begin{array}{l}\text { Destination serves multi- } \\
\text { market and a mix of } \\
\text { product, other factors } \\
\text { involved, are information } \\
\text { technology and disruptive } \\
\text { innovation. }\end{array}$ \\
\hline $\begin{array}{l}\text { Life Cycle } \\
\text { Stages }\end{array}$ & $\begin{array}{l}\text { Stages are not exact } \\
\text { sequences (Tooman, } \\
\text { 1997), the decline is not } \\
\text { compulsory (McKercher, } \\
\text { 2005) }\end{array}$ & $\begin{array}{l}\text { Stages evolve multi-time, } \\
\text { different destination and } \\
\text { diverse phases (Prideaux, } \\
2000 \text { ) }\end{array}$ & $\begin{array}{l}\text { Unable to set up the stage } \\
\text { boundaries. The evolution } \\
\text { of supply and demand. }\end{array}$ \\
\hline Timeframe & $\begin{array}{l}\text { No time boundaries. The } \\
\text { different impression of the } \\
\text { diverse market } \\
\text { (McKercher, 2005) }\end{array}$ & $\begin{array}{l}\text { Open-ended time mean } \\
\text { evolution (McKercher, } \\
\text { 2005a), life cycle has a } \\
\text { shorter time than evolution } \\
\text { (Singh, 2011) }\end{array}$ & $\begin{array}{l}\text { Investment (Hill and } \\
\text { Jones, 2010) and the } \\
\text { political agenda (Getz, } \\
\text { 1992) extend the time } \\
\text { frame. }\end{array}$ \\
\hline $\begin{array}{l}\text { Tourist } \\
\text { and local } \\
\text { responses }\end{array}$ & $\begin{array}{l}\text { Destination selection is } \\
\text { not ideal for personality } \\
\text { (Litvin, 2006), ignore } \\
\text { distance decay theory } \\
\text { (McKercher, 2018) }\end{array}$ & $\begin{array}{l}\text { The same perception is vital } \\
\text { for tourist and local } \\
\text { response related to } \\
\text { destination carrying } \\
\text { capacity (Singh, 2011) }\end{array}$ & $\begin{array}{l}\text { Market variation and } \\
\text { disruptive innovation } \\
\text { based on the new trend. } \\
\text { Number of Iconic marks } \\
\text { or the area of interest }\end{array}$ \\
\hline $\begin{array}{l}\text { Business } \\
\text { Purpose }\end{array}$ & $\begin{array}{l}\text { Not explicit. The market is } \\
\text { evolving (McKercher, } \\
\text { 2005). Ignore motivation, } \\
\text { activities, and } \\
\text { transportation (Litvin and } \\
\text { Smith, 2016) }\end{array}$ & $\begin{array}{l}\text { Not explicit. Understand } \\
\text { and strengthen position } \\
\text { (Getz, 1992; Haywood, } \\
\text { 1986) analytical tool } \\
\text { although not a guide or } \\
\text { strategy (Cooper and } \\
\text { Jackson, 1989) }\end{array}$ & $\begin{array}{l}\text { Need to understand } \\
\text { different kinds of } \\
\text { motivation and } \\
\text { expectation, various } \\
\text { activities and } \\
\text { transportation used } \\
\text { (Litvin and Smith, 2016) }\end{array}$ \\
\hline
\end{tabular}

Source: Synthesis from McKercher (2005, 2018); Litvin (2006); Litvin and Smith (2016); Prideaux (2000, 2004); Hill and Jones (2010); Getz (1992); Tooman (1997); Singh (2011); Haywood (1986); Cooper and Jackson (1989)

According to the final explanation in Table 1, the author reported that it is impossible to delineate the entire life cycle because of the complex factors involved in various destinations, which serves as the primary hypothesis. Several other reasons relating to the element are

1. Destination served multi-market and offered various kinds of product, including new technologies and disruptive innovation from entrepreneurs (both local and global).

2. Inability to set up time boundaries on every phase, because the fundamental economic law, such as supply and demand, is always evolving.

3. The destination receives new investment or a definite political agenda to increase growth rather than stagnancy or decline (or vice versa) 
4. The market evolves based on new trends or behaviour and generational difference, such as disruptive innovation.

5. The destination with good access to the market becomes an area of interest or a famous attraction (Iconic place), and there are relatively no strong competitors to withstand the extended period in the various stages.

6. Transportation, innovation, and technologies create faster and cheaper travel time thereby resulting in more accessible access to the destination (distance decay)

\section{E. CONCLUSION}

Based on the discussion, it is impossible to confidently map the entire destination life cycle without considering the complex factors stated. It is also possible assuming all tourism stakeholders agree to set up the elements involved, such as stages or boundaries, similar time frame perception, tourist and local perception of the market, and identical business purpose. However, it is quite tricky to realize an understanding of the high complexity of the destination equally. Furthermore, the purpose of the business point of view is to understand that the entire life cycle is not crucial.

In the rapid flow of industrial innovation, the generalisation of life cycle models is irrelevant (Hill and Jones, 2010). Tourist destinations with one or more industries in accordance with the various product offered are more concerned with the management of innovation. Therefore, the appropriate business model is created to experience the emerging trends in the future. At certain stages of the life cycle such as maturity, managers think of ways to avoid direct competition in order to avoid stagnation or decline, and there is a great possibility of survival (Okumus et al., 2010).

Adaptations and changes in accordance with the competitive environment are needed to resolve the challenges involved in developing a business model, thereby relieving companies of the difficulty of investigating the amount of investment to be made (Hill and Jones, 2010). According to the Authors, an essential matter relating to the models in this era of tourism industries that needs to handle by the DMO the changes due to innovation and collaboration among stakeholders. From all perspectives, measuring the entire destination life cycle is not as important as understanding their competitive position among rivalries.

Study related to the destination lifecycle is still needed in the future. The existing literature is not yet able to explain the distance and boundaries between cycle phases. Therefore, future research should focus on understanding the boundaries between the life cycles of destinations. In addition, research with the theme of the elements that affect the life cycle of a destination also needs to be done. Understanding these elements will contribute to the concept of a destination lifecycle.

\section{REFERENCES}

Butler, R. W. (1980). The Concept of a Tourist Area Cycle of Evolution: Implications for Management of Resources. Canadian Geographer, 24(1), 5-12. https://doi.org/10.1111/j.15410064.1980.tb00970.x

Choy, D. J. L. (1992). Life cycle models for Pacific island destinations. Journal of Travel Research, 30(3), 26-31. https://doi.org/10.1177/004728759203000304

Cooper, C., \& Jackson, S. (1989). Destination life cycle: The Isle of Man case study. Annals of Tourism Research, 16(3), 377-398. https://doi.org/10.1016/0160-7383(89)90051-0

Donald, G. (1992). Tourism planning and destination life cycle. Annals of Tourism Research, 19, $752-$ 770.

Goeldner, C. R. (2016). Stanley C. Plog - a renowned travel market researcher. Anatolia, 27(1), 120125. https://doi.org/10.1080/13032917.2015.1042750

Haywood, K. M. (1986). Can the tourist area cycle of evolution be made operational? Tourism Management, 7(3), 154-167. https://doi.org/10.1016/0261-5177(86)90002-6 
Hill, C. W., \& Jones, G. R. (2010). Strategic management Theory: An integrated approach (9th ed.). Mason: South-Western.

Kusumah, A.H.G., \& Azizah, G.R (2016). Tourism destination development model: A revisit to Butler's area life cycle. Heritage, Culture and Society: Research agenda and best practices in the hospitality and tourism industry.

Litvin, S. W. (2006). Revisiting Plog's model of allocentricity and psychocentricity... One more time. Cornell Hotel and Restaurant Administration Quarterly, 47(3), 245-253. https://doi.org/10.1177/0010880406289138

Litvin, S. W, \& Smith, W. (2016). A new perspective on the Plog psychographic system. Journal of Vacation Marketing, 22(2), 89-97.

McKercher, B. (2018a) Theories and concept in Tourism, Study Notes [Updated June 2018]. School of Hotel and Tourism Management, The Hong Kong Polytechnic University, Hong Kong. Retrieved from https://learn.polyu.edu.hk/bbcswebdav/pid-2970920-dt-content-rid11692357 1/courses/HTM6002 20181 A/HTM\%206002\%20-\%20full\%20notes\%20\%20updated\%20June\%202018.pdf

McKercher, B. (2018b) Theories and concept in Tourism, HTM 6002/ HTM 67006 [Power Point Slides]. School of Hotel and Tourism Management, The Hong Kong Polytechnic University, Hong Kong. Retrieved from https://learn.polyu.edu.hk/webapps/blackboard/execute/content/file?cmd=view\&content $\underline{\mathrm{id}=} 2970921 \quad 1 \&$ course $\mathrm{id}=643631$ 1\&framesetWrapped=true

McKercher, B. (2005a). Destinations as products? A reflection on butler's life cycle. Tourism Recreation Research, 30(3), 97-102. https://doi.org/10.1080/02508281.2005.11081491

McKercher, B. (2005b). Are Psychographics Predictors of Destination Life Cycles? Journal of Travel \& Tourism Marketing, 19(1), 49-55. https://doi.org/10.1300/J073v19n01_05

Mckercher, B., Chan, A., \& Lam, C. (2008). The Impact of Distance on International Tourist Movements. Journal of Travel Research, 47 (2), 208-224. https://doi.org/10.1177/0047287508321191

Okumus, F., Altinay, L., \& Chathoth, P. (2010). Strategic management for hospitality and tourism (1st ed.). Elsevier/ Butterworth-Heinemann.

Oppermann, M. (1998). What is New with the Resort Cycle? Tourism Management, 19(2), 179-180. https://doi.org/10.1016/S0261-5177(97)00118-0

Plog, S. C. (1974). Why Destination Areas Rise and Fall in Popularity. Cornell Hotel and Restaurant Administration Quarterly, 14(4), 55-58. https://doi.org/10.1177/001088047401400409

Plog, S. (2001). Why Destination Areas Rise and Fall in Popularity: An update of a Cornell Quarterly Classic. Cornell Hotel and Restaurant Administration Quarterly, 42(3)(June), 13-24. https://doi.org/10.1177/0010880401423001

Prideaux, B. (2004). The resort development spectrum: The case of the Gold Coast, Australia. Tourism Geographies (Vol. 6). https://doi.org/10.1080/14616680320001722328

Prideaux, B. (2000). The resort development spectrum - a new approach to modeling resort development. Tourism Management, 21(3), 225-240. https://doi.org/10.1016/S02615177(99)00055-2

Singh, S. (2011). The tourism area "life cycle": A clarification. Annals of Tourism Research, 38(3), 1185-1187. https://doi.org/10.1016/j.annals.2011.03.005

Tooman, L. A. (1997). Applications of the life-cycle model in tourism. Annals of Tourism Research, 24(1), 214-234. https://doi.org/10.1016/S0160-7383(96)00052-7 